Vol. 41: 21-27, 2013

\title{
Yield and yield components of wheat as affected by phosphorus fertilization
}

\author{
M. S. Alam* \& I. Jahan \\ Department of Agronomy and Agricultural Extension, University of Rajshahi, \\ Rajshahi 6205, Bangladesh. \\ *Corresponding author:sami_ratan@yahoo.com
}

\begin{abstract}
The experiment was conducted at the Agronomy Field laboratory, Department of Agronomy and Agricultural Extension, University of Rajshahi to study the yield and yield components of wheat as affected by phosphorus fertilization. The experiment consisted of two factors i.e. (i) three wheat varieties viz., Shatabdi, Bijoy and Prodip and (ii) five levels of phosphorus viz. 0, 30, 60, 90, 120 kg $\mathrm{P}_{2} \mathrm{O}_{5}$ $\mathrm{ha}^{-1}$. A RCBD design was used for the experiment with three replications. The effect of variety was significant on all the yield components and yield except plant height. Prodip gave the highest grain yield $\left(3.67 \mathrm{t} \mathrm{ha}^{-1}\right)$ followed by Bijoy $\left(3.45 \mathrm{tha}^{-1}\right)$ and Shatabdi $\left(3.28 \mathrm{t} \mathrm{ha}^{-1}\right)$. Yield and yield components of wheat were significantly influenced by different levels of phosphorus. The highest grain yield $\left(4.47 \mathrm{tha}^{-1}\right)$ was recorded from $\mathrm{P}_{4}\left(120 \mathrm{~kg} \mathrm{P}_{2} \mathrm{O}_{5} \mathrm{ha}^{-1}\right)$ and the lowest one $(2.43 \mathrm{t}$ $\left.\mathrm{ha}^{-1}\right)$ from the control treatment. The highest grain yield $\left(4.80 \mathrm{t} \mathrm{ha}^{-1}\right)$ was obtained from Prodip at $120 \mathrm{~kg} \mathrm{P}_{2} \mathrm{O}_{5} \mathrm{ha}^{-1}$ and the lowest one $\left(2.3 \mathrm{t} \mathrm{ha}^{-1}\right)$ was found in Shatabdi at control treatment. The results suggest that the combination of $\mathrm{V}_{3} \mathrm{P}_{4}$ (Prodip with $120 \mathrm{~kg} \mathrm{P}_{2} \mathrm{O}_{5}$ ha $^{-1}$ ) is the best for obtaining higher yield of wheat.
\end{abstract}

Keywords: Variety, wheat, phosphorus and yield.

\section{Introduction}

Wheat is one of the most important cereal crops in the world and it has the widest distribution among the cereal crops. The crop is primarily grown for its grain, which is consumed as human food. It was introduced in Mexico by the Spaniards in the early part of $16^{\text {th }}$ century and into Virginia, USA by English colonists early in the $17^{\text {th }}$ century. In Bangladesh, it is recognized as the second alternative cereal crop in respect of total area of land having an annual production of 7.35,926 metric tons and total area of 1138700 hectares (BBS, 2008). Though, wheat is an important cereal crop in Bangladesh, its average yield is low compared to other advanced countries of the world. In Bangladesh, the area under wheat cultivation was 7.06, 6.42, 5.56 and 4.81 lakh hectares in 2002-2003, 2003-04, 2004-05, 2005-06 respectively and the production was 15.07, 12.53, 10.50 and 7.72 lakh metric tons in respective years (DAE, 2008). Several factors such as good varieties, adequate cultural practices like balanced fertilization etc are very important for higher production of crops like wheat. The variety is one of the factors which play an important role in producing higher yield of wheat. Fertilizers are marvelous instruments if wisely used but highly dangerous if wrongly applied. The use of nutrient materials through fertilizer as a means of supplementing the natural food supplies in the soil. Phosphorus is an important nutrient element for wheat plant. Adequate quantity in available source of phosphorus is vital for the growth, reproduction, yield and quality of wheat. Phosphorus is essential for cell division, seed and fruit development (Ahmad \& Rashid, 2003). Application of 
adequate amount of phosphorus improves the grain yield. Thus there is a need to derive the adequate level of phosphorus for obtaining higher yield with good quality of wheat. Kaleem et al. (2009) conducted a field experiment to determine the judicious use of phosphorus at Adaptive Research Farm, Dera Ghazi Khan during 2001-02 to find out the effect of best phosphorus level on wheat variety Inqlab-91. Five different phosphorus levels i.e.32, 42, 84, 96 and $128 \mathrm{~kg} \mathrm{P} \mathrm{ha}^{-1}$ were used in the experiment. Maximum grain yield was obtained at $128 \mathrm{~kg} \mathrm{P} \mathrm{ha}^{-1}$ indicating importance of phosphorus at its highest dose in achieving maximum wheat productivity. Maximum phosphorus dose contributed in achieving highest 1000 grain weight and finally resulted in statistically significant grain yield ha ${ }^{-1}$. These findings indicate that application of the highest dose of phosphorus contributed maximum dry matter and physiological attributes towards the yield attributes in wheat variety, Inqlab-91 and therefore maximum phosphorus dose helped in achieving highest number of grains spike $^{-1}$, 1000 grain weight and ultimately wheat yield. Due to deficiency of phosphorus, growth of root and shoot is restricted, plants are thin and spindly, premature shedding of leaves and flowering occur, yields are consequently decreased. Considering the above information, the present study was undertaken to study the yield and yield components of wheat varieties as affected by phosphorus fertilization.

\section{Materials and methods}

The present research work was carried out at Agronomy Field Laboratory, Department of Agronomy and Agricultural Extension, University of Rajshahi during November, 2011 to April 2012. The experiment consisted of two factors i.e. (i) three wheat varieties viz. Shatabdi $\left(V_{1}\right)$, Bijoy $\left(V_{2}\right)$ and Prodip $\left(V_{3}\right)$ and (ii) five levels of phosphorus viz. $0\left(\mathrm{P}_{0}\right), 30\left(\mathrm{P}_{1}\right), 60\left(\mathrm{P}_{2}\right), 90\left(\mathrm{P}_{3}\right), 120\left(\mathrm{P}_{4}\right) \mathrm{kg} \mathrm{P}_{2} \mathrm{O}_{5}$ ha $^{-}$ ${ }^{1}$. A RCBD design was used for the experiment with three replications. The size of the unit plot was $2 \mathrm{~m} \times 2 \mathrm{~m}$. The experimental land was prepared with tractor drawn disc plough and country plough followed by laddering for breaking the clods and leveling the soil to obtain desirable tilth. Weeds and stubbles were removed. Urea, muriate of potash and gypsum were applied to the plots at the rate of 220, 50, 120 $\mathrm{kg} \mathrm{ha}^{-1}$ during the final land preparation. Phosphorus fertilizer was applied as per experimental specification. Nitrogenous fertilizer was applied in two installments; two-thirds at the time of final land preparation and one-third at 27 days after sowing. All the applied fertilizers were thoroughly mixed to the soil. Seeds were sown in $25 \mathrm{~cm}$ apart rows opened by specially made an iron hand tine. After sowing the seeds were covered with soil and slightly pressed by hands. Intercultural operations were done as and when necessary. Data on yield and yield components were recorded from ten randomly selected plants in each plot. The data were analyzed statistically using the analysis of variance technique and the mean differences among the treatments were adjudged by new Duncan's Multiple Range Test (DMRT) (Gomez \& Gomez, 1984) with the help of MSTAT software.

\section{Results and discussion}

\section{Plant height}

Plant height responded significantly due to variety (Table 1). Prodip had the tallest $(103.80 \mathrm{~cm})$ plant followed by Bijoy $(103.40 \mathrm{~cm})$ and Shatabdi $(102.90 \mathrm{~cm})$. This is due to genetic makeup among the varieties. Plant height was significantly 
influenced by phosphorus level (Table 1$)$. The tallest plant $(105.30 \mathrm{~cm})$ was observed in $120 \mathrm{~kg} \mathrm{P}_{2} \mathrm{O}_{5}$ ha $^{-1}$ and the shortest plant was found $(101.30 \mathrm{~cm})$ in control treatment where no phosphorus was applied. Plant height was statistically not significant to the interaction of variety and phosphorus level. The tallest plant $(105.76 \mathrm{~cm})$ was obtained from the variety Prodip in $\mathrm{V}_{3} \mathrm{P}_{3}$ combination and the lowest $(100.61 \mathrm{~cm})$ in Shatabdi in $\mathrm{V}_{1} \mathrm{P}_{0}$ treatment (Table 2).

Table 1. Effect of variety and phosphorus levels on the yield and yield components of wheat.

\begin{tabular}{|c|c|c|c|c|c|c|c|c|c|}
\hline Variety & $\begin{array}{l}\text { Plant } \\
\text { height } \\
(\mathrm{cm})\end{array}$ & $\begin{array}{c}\text { Total } \\
\text { tillers } \\
\text { plant }^{-1} \\
\text { (no.) }\end{array}$ & \begin{tabular}{|c|} 
Effective \\
tillers \\
plant $^{-1}$ \\
(no.)
\end{tabular} & $\begin{array}{l}\text { Spike } \\
\text { length } \\
(\mathrm{cm})\end{array}$ & \begin{tabular}{|c|} 
Spikelets \\
spike $^{-1}$ \\
(no.)
\end{tabular} & $\begin{array}{c}\text { Fertile } \\
\text { spikelets } \\
\text { spike }^{-1} \\
\text { (no.) }\end{array}$ & $\begin{array}{c}\text { Grains } \\
\text { spike }^{-1} \\
\text { (no) }\end{array}$ & $\begin{array}{c}1000 \\
\text { grain } \\
\text { weight } \\
\text { (g) }\end{array}$ & $\begin{array}{c}\text { Grain } \\
\text { yield } \\
\left(\mathrm{t} \mathrm{ha}^{-1}\right)\end{array}$ \\
\hline $\mathrm{V}_{1}$ & 102.90b & $5.39 \mathrm{~b}$ & $3.40 \mathrm{c}$ & 9.94 & 31.47ab & $20.23 b$ & $44.10 \mathrm{c}$ & $48.95 c$ & $3.28 \mathrm{c}$ \\
\hline $\mathrm{V}_{2}$ & 103.40a & 5.73a & $3.55 b$ & 10.62 & $30.31 b$ & $19.75 b$ & $46.61 \mathrm{~b}$ & $55.26 \mathrm{~b}$ & $3.45 b$ \\
\hline $\mathrm{V}_{3}$ & 103.80a & $5.80 \mathrm{a}$ & $3.74 a$ & 11.35 & $33.32 \mathrm{a}$ & $21.87 \mathrm{a}$ & $49.12 a$ & $58.60 \mathrm{a}$ & $3.67 a$ \\
\hline LS & 0.05 & 0.01 & 0.01 & 0.01 & 0.01 & 0.01 & 0.01 & 0.01 & 0.01 \\
\hline CV (\%) & 2.46 & 1.68 & 1.68 & 5.89 & 7.11 & 4.30 & 3.23 & 5.44 & 2.67 \\
\hline \multicolumn{10}{|c|}{ Phosphorus levels } \\
\hline $\mathrm{P}_{0}$ & 101.30b & $4.33 \mathrm{e}$ & $2.73 e$ & $9.75 \mathrm{c}$ & $28.98 b$ & $19.44 \mathrm{~b}$ & $33.89 \mathrm{e}$ & $50.16 c$ & $2.43 \mathrm{e}$ \\
\hline $\mathrm{P}_{1}$ & $102.40 \mathrm{ab}$ & $4.76 \mathrm{~d}$ & $3.09 \mathrm{~d}$ & $10.40 \mathrm{bc}$ & $30.91 \mathrm{ab}$ & $20.40 \mathrm{ab}$ & $39.27 d$ & $52.79 \mathrm{bc}$ & $2.97 d$ \\
\hline $\mathrm{P}_{2}$ & 103.40ab & 5.71c & $3.41 \mathrm{c}$ & 10.75ab & $31.96 a$ & $20.57 \mathrm{ab}$ & $45.22 \mathrm{c}$ & 54.91ab & $3.52 \mathrm{c}$ \\
\hline $\mathrm{P}_{3}$ & 104.40ab & $6.32 \mathrm{~b}$ & $3.97 \mathrm{~b}$ & 10.98ab & $33.00 \mathrm{a}$ & $21.18 \mathrm{a}$ & $53.84 \mathrm{~b}$ & 55.32ab & $3.94 b$ \\
\hline $\mathrm{P}_{4}$ & 105.30a & $7.07 a$ & $4.61 \mathrm{a}$ & $11.29 a$ & $33.66 a$ & $21.48 \mathrm{a}$ & $60.82 a$ & $58.18 a$ & $4.47 \mathrm{a}$ \\
\hline LS & 0.05 & 0.01 & 0.01 & 0.01 & 0.01 & 0.01 & 0.01 & 0.01 & 0.01 \\
\hline CV (\%) & 2.46 & 1.68 & 1.68 & 5.89 & 7.11 & 4.30 & 3.23 & 5.44 & 2.67 \\
\hline
\end{tabular}

In a column the figures beating same letter (s) are identical and those having dissimilar letters differed significantly as per DMRT.

$\mathrm{V}_{1}=$ Shatabdi, $\mathrm{V}_{2}=$ Bijoy, $\mathrm{V}_{3}=$ Prodip, $\mathrm{P}_{0}=0 \mathrm{~kg} \mathrm{P}_{2} \mathrm{O}_{5} \mathrm{ha}^{-1}, \mathrm{P}_{1}=30 \mathrm{~kg} \mathrm{P}_{2} \mathrm{O}_{5} \mathrm{ha}^{-1}, \mathrm{P}_{2}=60 \mathrm{~kg}$ $\mathrm{P}_{2} \mathrm{O}_{5} \mathrm{ha}^{-1}, \mathrm{P}_{3}=90 \mathrm{~kg} \mathrm{P}_{2} \mathrm{O}_{5} \mathrm{ha}^{-1}, \mathrm{P}_{4}=120 \mathrm{~kg} \mathrm{P}_{2} \mathrm{O}_{5} \mathrm{ha}^{-1}$, LS = Level of significance, CV= Coefficient of variation,

Total tillers plant ${ }^{-1}$

The number of total tillers plant ${ }^{-1}$ was statistically significant in different varieties. Prodip produced the highest number of total tillers plant ${ }^{-1}(5.80)$ which was statistically similar with Bijoy (5.73) whereas Shatabdi produced the lowest (5.39) (Table 1). This is due to the genetic makeup and the varietals differences among the varieties. This result is in similar to that view of Rahim et al. (2010). Significant variation was observed in terms of number of total tillers plant ${ }^{-1}$ in respect of phosphorus level. The maximum number of total tillers plant ${ }^{-1}$ (7.07) was recorded from $\mathrm{P}_{4}\left(120 \mathrm{~kg} \mathrm{P}_{2} \mathrm{O}_{5} \mathrm{ha}^{-1}\right)$ and the minimum one (4.33) was observed in $\mathrm{P}_{0}$ (control treatment) (Table 1).This results are in line with that of Alam et al. (2003) who reported that the application of phosphorus fertilizer to wheat significantly increase the number of tillers plant ${ }^{-1}$. It was observed that number of total tillers plant $^{-1}$ was significantly influenced by the interaction of variety and phosphorus. The highest number of total tillers plant ${ }^{-1}(7.40)$ was obtained from the combination of $\mathrm{V}_{3} \mathrm{P}_{4}$ (Prodip with $120 \mathrm{~kg} \mathrm{P}_{2} \mathrm{O}_{5}$ ha $^{-1}$ ) and the lowest (4.20) was obtained from $\mathrm{V}_{1} \mathrm{P}_{0}$ (Shatabdi at control) combination (Table 2). 
Table 2. Interaction effect of variety and phosphorus levels on the yield and yield components of wheat.

\begin{tabular}{|c|c|c|c|c|c|c|c|c|c|}
\hline $\begin{array}{c}\text { Variety } \times \\
\text { Phosphorus } \\
\text { levels }\end{array}$ & $\begin{array}{l}\text { Plant } \\
\text { height } \\
(\mathrm{cm})\end{array}$ & $\begin{array}{l}\text { Total } \\
\text { tillers } \\
\text { plant }^{-1} \\
\text { (no.) }\end{array}$ & $\begin{array}{c}\text { Effective } \\
\text { tillers } \\
\text { plant }^{-1} \\
\text { (no.) } \\
\end{array}$ & \begin{tabular}{|c|} 
Spike \\
length \\
$(\mathrm{cm})$
\end{tabular} & $\begin{array}{c}\text { Spikelets } \\
\text { spike }^{-1} \\
\text { (no.) }\end{array}$ & \begin{tabular}{|c|} 
Fertile \\
spikelets \\
spike $^{-1}$ \\
(no.) \\
\end{tabular} & $\begin{array}{l}\text { Grains } \\
\text { Spike }^{-1} \\
\text { (no.) }\end{array}$ & \begin{tabular}{|c|}
1000 \\
grain \\
weight \\
$(\mathrm{g})$ \\
\end{tabular} & $\begin{array}{l}\text { Grain } \\
\text { yield } \\
\left(\mathrm{t} \mathrm{ha}^{-1}\right)\end{array}$ \\
\hline $\mathrm{V}_{1} \mathrm{P}_{0}$ & 100.61 & $4.20 \mathrm{k}$ & $2.67 j$ & 8.92 & 27.46 & 18.26 & 32.40 & 43.86 & 2.30 \\
\hline $\mathrm{V}_{1} \mathrm{P}_{1}$ & 101.96 & 4.63hi & $2.99 \mathrm{i}$ & 9.52 & 30.80 & 20.33 & 37.06 & 46.26 & 2.80 \\
\hline $\mathrm{V}_{1} \mathrm{P}_{2}$ & 103.10 & $5.36 \mathrm{f}$ & 3.23h & 10.16 & 32.60 & 20.40 & 42.60 & 49.90 & 3.33 \\
\hline $\mathrm{V}_{1} \mathrm{P}_{3}$ & 104.10 & $6.00 \mathrm{e}$ & $3.80 \mathrm{e}$ & 10.24 & 33.00 & 20.80 & 51.30 & 50.23 & 3.80 \\
\hline $\mathrm{V}_{1} \mathrm{P}_{4}$ & 104.86 & $6.76 \mathrm{c}$ & $4.33 c$ & 10.85 & 33.50 & 21.33 & 57.13 & 54.50 & 4.20 \\
\hline $\mathrm{V}_{2} \mathrm{P}_{0}$ & 101.46 & $4.33 \mathrm{jk}$ & $2.75 \mathrm{j}$ & 10.17 & 28.46 & 18.93 & 33.46 & 49.56 & 2.40 \\
\hline $\mathrm{V}_{2} \mathrm{P}_{1}$ & 102.60 & 4.70h & 3.10hi & 10.40 & 29.06 & 19.33 & 39.30 & 53.86 & 2.93 \\
\hline $\mathrm{V}_{2} \mathrm{P}_{2}$ & 103.43 & $6.23 d$ & $3.40 \mathrm{~g}$ & 10.45 & 29.66 & 19.40 & 45.60 & 55.36 & 3.53 \\
\hline $\mathrm{V}_{2} \mathrm{P}_{3}$ & 104.33 & $6.33 d$ & $4.00 \mathrm{~d}$ & 10.88 & 31.93 & 20.40 & 53.33 & 57.63 & 3.96 \\
\hline $\mathrm{V}_{2} \mathrm{P}_{4}$ & 105.26 & $7.06 \mathrm{~b}$ & $4.50 \mathrm{~b}$ & 11.17 & 32.40 & 20.66 & 61.33 & 59.86 & 4.43 \\
\hline $\mathrm{V}_{3} \mathrm{P}_{0}$ & 101.90 & $4.46 \mathrm{ij}$ & $2.78 \mathrm{j}$ & 10.18 & 31.00 & 21.13 & 35.80 & 57.03 & 2.60 \\
\hline $\mathrm{V}_{3} \mathrm{P}_{1}$ & 102.73 & $4.96 \mathrm{~g}$ & $3.20 \mathrm{~h}$ & 11.28 & 32.86 & 21.53 & 41.43 & 58.23 & 3.20 \\
\hline $\mathrm{V}_{3} \mathrm{P}_{2}$ & 103.76 & $5.53 \mathrm{f}$ & $3.60 \mathrm{f}$ & 11.63 & 33.60 & 21.90 & 47.46 & 59.46 & 3.70 \\
\hline $\mathrm{V}_{3} \mathrm{P}_{3}$ & 104.66 & $6.63 c$ & $4.13 \mathrm{~d}$ & 11.81 & 34.06 & 22.33 & 56.90 & 58.10 & 4.06 \\
\hline $\mathrm{V}_{3} \mathrm{P}_{4}$ & 105.76 & $7.40 \mathrm{a}$ & $5.00 \mathrm{a}$ & 11.85 & 35.06 & 22.43 & 64.0 & 60.16 & 4.80 \\
\hline LS & NS & 0.01 & 0.01 & NS & NS & NS & NS & NS & NS \\
\hline CV (\%) & 2.46 & 1.68 & 1.68 & 5.89 & 7.11 & 4.3 & 3.23 & 5.44 & 2.67 \\
\hline
\end{tabular}

In a column the figures beating same letter (s) or without letters are identical and those having dissimilar letters differed significantly as per DMRT,

NS= Non significant.

Effective tillers plant ${ }^{-I}$

Number of effective tillers plant ${ }^{-1}$ responded significantly due to variety. The maximum number of effective tillers plant ${ }^{-1}$ (3.74) was produced by Prodip. The minimum number of effective tillers plant ${ }^{-1}$ (3.40) was produced by Shatabdi (Table 1). Varietal differences regarding the production of effective tillers plant ${ }^{-1}$ may be due to their genetic makeup as well as environmental factors. Rahim et al. (2010) also found that Prodip produced the highest number of effective tillers plant $^{-1}$ than the other varieties. Significant variation was observed in terms of number of effective tillers plant ${ }^{-1}$ due to different levels of phosphorus. The maximum number of effective tillers plant ${ }^{-1}$ (4.61) was recorded at $\mathrm{P}_{4}(120 \mathrm{~kg}$ $\mathrm{P}_{2} \mathrm{O}_{5} \mathrm{ha}^{-1}$ ) and the minimum one (2.73) in the control treatment (Table 1). The number of effective tillers plant ${ }^{-1}$ was significantly influenced by the interaction of variety and phosphorus. The highest number of effective tillers plant ${ }^{-1}$ (5.00) was obtained from the combination of $\mathrm{V}_{3} \mathrm{P}_{4}$ (Prodip with $120 \mathrm{~kg}_{2} \mathrm{O}_{5} \mathrm{ha}^{-1}$ ) and the lowest one (2.67) was obtained from $\mathrm{V}_{1} \mathrm{P}_{0}$ (Shatabdi at control) combination which was statistically similar with $\mathrm{V}_{2} \mathrm{P}_{0}$ (Bijoy with control) and $\mathrm{V}_{3} \mathrm{P}_{0}$ combination (Prodip with control treatment) (Table 2).

Spike length

Variety had significant effect on spike length. The tallest spike $(11.35 \mathrm{~cm})$ was produced by Prodip and the shortest one $(9.94 \mathrm{~cm}$ ) was given by Shatabdi (Table 1). Significant variation was observed in terms of spike length due to phosphorus 
levels. The longest spike $(11.29 \mathrm{~cm})$ was recorded from $\mathrm{P}_{4}$ and the shortest one $(9.75 \mathrm{~cm})$ was observed at $\mathrm{P}_{0}$ (control) (Table 1). It was observed that application of phosphorus had a marked influence on spike length of wheat, which is supported by Rahim et al. (2010). Significant effect was not observed in respect of spike length due to the interaction of variety and phosphorus. Apparently the longest spike $\left(11.85 \mathrm{~cm}\right.$ ) was noted from combination of $\mathrm{V}_{3} \mathrm{P}_{4}$ (Prodip with $120 \mathrm{~kg}$ $\mathrm{P}_{2} \mathrm{O}_{5} \mathrm{ha}^{-1}$ ) and the lowest one $\left(8.92 \mathrm{~cm}\right.$ ) was obtained from $\mathrm{V}_{1} \mathrm{~T}_{0}$ (Shatabdi at control) treatment (Table 2).

\section{Spikelets spike ${ }^{-1}$}

Number of spikelets spike ${ }^{-1}$ was significantly influenced due to different varieties. The highest number of spikelets spike ${ }^{-1}$ (33.32) was produced by Prodip and the lowest one (30.31) was produced by Bijoy which was statistically similar with Shatabdi (Table 1). These results are in conformity with that of Rahim et al. (2010). An experiment was conducted in the farmer's field of ICM club members, Godagari, Rajshahi during 2009-10 to evaluate the performance of different wheat varieties in High Barind Tract. Among the five varieties, significantly the highest number of spikelets spike ${ }^{-1}$ was recorded from Prodip and the lowest spikelets spike $^{-1}$ was obtained from Bijoy (BARI, 2010). Significant variation was observed in respect of number of spikelets spike ${ }^{-1}$ due to phosphorus application rate. The highest number of spikelets spike ${ }^{-1}$ (33.66) was observed in $\mathrm{P}_{4}\left(120 \mathrm{~kg} \mathrm{P}_{2} \mathrm{O}_{5}\right.$ ha $\left.^{-1}\right)$ and the lowest one (28.98) was observed at $\mathrm{P}_{0}$ (control treatment) (Table 2). Rahim et al. (2010) also reported that application of $\mathrm{P}$ increased the spikelets spike $^{-1}$. Significant effect was not observed in respect of number of spikelets spike${ }^{1}$ due to the interaction of variety and phosphorus. Apparently the highest spikelets spike ${ }^{-1}$ (35.06) was noted from the combination of $\mathrm{V}_{3} \mathrm{P}_{4}$ (Prodip with $120 \mathrm{~kg} \mathrm{P}_{2} \mathrm{O}_{5}$ $\mathrm{ha}^{-1}$ and the lowest one (27.46) was obtained from $\mathrm{V}_{1} \mathrm{P}_{0}$ (Shatabdi at control) combination (Table 2).

Fertile spikelets spike ${ }^{-1}$

There was a significant variation among the varieties in terms of number of fertile

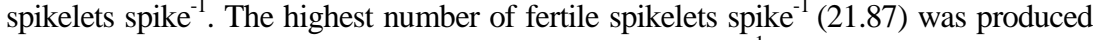
by Prodip and the lowest number of fertile spikelets spike ${ }^{-1}$ (19.75) was produced by Bijoy which was statistically similar with Shatabdi (Table 1). Significant variation was observed in respect of number of fertile spikelets spike ${ }^{-1}$ due to phosphorus. The highest number of fertile spikelets spike ${ }^{-1}$ (21.48) was observed in $\mathrm{P}_{4}$ and the lowest (19.44) at control $\left(\mathrm{P}_{0}\right)$ (Table 1). Number of fertile spikelets spike ${ }^{-1}$ due to the interaction of variety and phosphorus application rate was not statistically significant though the highest number of fertile spikelets spike ${ }^{-1}$ (22.43) was counted from the combination of $\mathrm{V}_{3} \mathrm{P}_{4}$ (Prodip with $120 \mathrm{~kg}_{2} \mathrm{O}_{5}$ ha $^{-1}$ ) and the lowest one (18.26) was recorded from $\mathrm{V}_{1} \mathrm{P}_{0}$ (Shatabdi at control) treatment (Table 2).

\section{Grains spike $^{-1}$}

The number of grains spike ${ }^{-1}$ was affected significantly by the variety. The highest number of grains spike ${ }^{-1}$ (49.12) was produced by Prodip and lowest one (44.10) was produced by Shatabdi (Table 1). This result is in agreement with the view of Rahim et al. (2010). Significant variation was also observed in respect of number of grains spike ${ }^{-1}$ due to application rate of phosphorus. The highest number of 
grains spike ${ }^{-1}$ (60.82) was observed in $\mathrm{P}_{4}$ and the lowest one (33.89) was observed at $\mathrm{P}_{0}$ (control treatment) (Table 1 ). Number of grains spike ${ }^{-1}$ due to the interaction of variety and phosphorus was not significant though the highest number of grains spike ${ }^{-1}$ (64.00) was noted from the combination of $\mathrm{V}_{3} \mathrm{P}_{4}$ (Prodip with $120 \mathrm{~kg} \mathrm{P}_{2} \mathrm{O}_{5}$ $\mathrm{ha}^{-1}$ ) and the lowest one (32.40) was obtained from $\mathrm{V}_{1} \mathrm{P}_{0}$ (Shatabdi at control treatment) (Table 2).

\section{0-grain weight}

Variety had significant effect on 1000-grain weight of wheat. The weight of 1000grain for the varieties followed an order: Prodip $>$ Bijoy $>$ Shatabdi with the values $58.60,55.26$, and 48.95 g respectively (Table 1 ). Significant variation was observed in respect of 1000-grain weight due to phosphorus application rate. The highest 1000-grain weight (58.18 g) was observed in $\mathrm{P}_{4}\left(120 \mathrm{~kg} \mathrm{P}_{2} \mathrm{O}_{5} \mathrm{ha}^{-1}\right)$ and the lowest (50.16 g) was observed at $\mathrm{P}_{0}$ (control) treatment (Table 1). Rehman et al. (2004) observed that 1000-grain weight increased significantly with increase in $\mathrm{P}$ rate. Relatively heavier grains were produced with $120 \mathrm{~kg} \mathrm{P}_{2} \mathrm{O}_{5} \mathrm{ha}^{-1}$ as a result 1000 grain weight increased consequently. Thousand-grain weight due to the interaction of variety and phosphorus was not statistically significant. The highest 1000-grain weight (60.16 g) was noted from combination $\mathrm{V}_{3} \mathrm{P}_{4}$ (Prodip with $120 \mathrm{~kg} \mathrm{P}_{2} \mathrm{O}_{5}$ ha $^{-1}$ ) and the lowest one (43. $86 \mathrm{~g}$ ) was obtained from $\mathrm{V}_{1} \mathrm{P}_{0}$ (Shatabdi at control) treatment (Table 2).

\section{Grain yield}

The grain yield was affected significantly by the variety. The highest grain yield $\left(3.67 \mathrm{t} \mathrm{ha}^{-1}\right.$ ) was produced by Prodip and the lowest one (3.28 $\left.\mathrm{t} \mathrm{ha}^{-1}\right)$ by Shatabdi (Table 1). This is due to varietal potentialities that Prodip produced the highest grain yield. Singh et al. (1995) also found that Prodip produced the highest grain yield than rest of the varieties. An experiment was conducted in the farmer's field of 1CM club members, Godagari, Rajshahi during 2009-10 to evaluate the performance of different wheat varieties in High Barind Tract where significantly the highest grain yield (4.33 $\left.\mathrm{tha}^{-1}\right)$ were recorded from Prodip and the lowest grain yield (4.06 t ha $\mathrm{t}^{-1}$ ) was obtained from Bijoy (BARI, 2010). Significant variation was observed in respect of grain yield due to different phosphorus levels. The highest grain yield (4.47 $\left.\mathrm{t} \mathrm{ha}^{-1}\right)$ was observed in $\mathrm{P}_{4}\left(120 \mathrm{~kg} \mathrm{P}_{2} \mathrm{O}_{5} \mathrm{ha}^{-1}\right)$ and the lowest $\left(2.43 \mathrm{t} \mathrm{ha}^{-1}\right.$ ) was observed at $\mathrm{P}_{0}$ (control) treatment (Table 1$)$. These results are in confirmation with the findings of Islam \& Baten (1987) and Patel et al.(1991) who recorded maximum yield by the application of appropriate $\mathrm{P}$ rate, which was reduced in treatments receiving $P$ in inappropriate rate. This could be the result of reduced plant senescence rate at the grain filling stage and longer duration of green leaf area duration with the application of phosphorus as observed by Colomb et al.(2000). Significant effect was not observed in respect of grain yield due to the interaction of variety and phosphorus. Apparently the highest grain yield (4.80 $\mathrm{t} \mathrm{ha}^{-1}$ ) was noted from combination of $\mathrm{V}_{3} \mathrm{P}_{4}$ (Prodip with $120 \mathrm{~kg}$ $\mathrm{P}_{2} \mathrm{O}_{5} \mathrm{ha}^{-1}$ ) and the lowest one $\left(2.30 \mathrm{t} \mathrm{ha}^{-1}\right)$ was obtained from $\mathrm{V}_{1} \mathrm{P}_{0}$ (Shatabdi at control) treatment (Table 2). Kaleem et al. (2009) also reported that maximum grain yield was obtained in the plots where higher rate of phosphorus was applied. Maximum phosphorus dose contributed in achieving highest 1000 grain weight and finally resulted in statistically significant grain yield $\mathrm{ha}^{-1}$. These findings 
indicate that application of the highest dose of phosphorus contributed to maximum dry matter and physiological attributes towards the yield attributes in wheat and therefore helped in achieving highest number of grains spike ${ }^{-1}, 1000$ grain weight and ultimately yield of wheat.

It may be concluded that Prodip showed better performance for grain yield and yield components of wheat and consequently it produced the highest grain yield. The highest grain yield was obtained when $120 \mathrm{~kg} \mathrm{P} \mathrm{ha}^{-1}$ was applied. Finally, the results suggest that the combination of $\mathrm{V}_{3} \mathrm{P}_{4}$ (Prodip with $120 \mathrm{~kg} \mathrm{P}_{2} \mathrm{O}_{5} \mathrm{ha}^{-1}$ ) is the best combination for obtaining higher yield of wheat.

\section{References}

Alam, S.M., Azam, S., Ali, S. \& Iqbal, M. 2003. Wheat yield and P fertilizer efficiency as influenced by rate and integrated use of chemical and organic fertilizers. Pak. J. Soil Sci., 22(2): 72-76.

Ahmad, N. \& Rashid, M. 2003. Fertilizer and their use in Pakistan. National Fertilizer Development Centre, Government of Pakistan: 41-45.

BARI (Bangladesh Agricultural Research Institute), 2010. Annual Report 2009-2010. Bangladesh Agril. Res. Inst., Gazipur: 31.

BBS (Bangladesh Bureau of Statisics), 2008. Monthly Statistical Bulletin of Bangladesh. Stat. Div., Ministry Planning, Dhaka: 136-140.

Colomb, B., Kiniry, J.R. \& Deback, P. 2000. Effect of soil phosphorus on leaf development and senescence dynamics of field grown maize. Agron. J., 92: 428-435.

DAE 2008. Annual Report 2006-2007. Ministry of Agriculture, Dhaka: 136-140.

Gomez, K.A. \& Gomez, A.A. 1984. Statistical procedures for agricultural research. $2^{\text {nd }}$ edn. John Willey \& Sons, New York: 97-411.

Islam, M.A. \& Baten, M.A. 1987. Growth and yield of wheat as affected by different levels of N and P. Thai J. Agric. Sci, 20(3) Absts., 42(6): 3886:1989.

Patel, N.M., Patel, R.B. \& Patel, K.K. 1991. Response of wheat varieties to N and P. Ind. J. Agron, 36: 255-256. (Field Crop Absts., 46(9): 5450:1993).

Kaleem, S., Ansar, M. Ali, M.A., Sher, A., Ahmad, G. \& Rashid, M. 2009. Effect of phosphorus on the yield and yield components of wheat variety "inqlab-91" under rainfed conditions. Sarhad J. Agric., 25(1): 21-24.

Rahim, A., Ranjha, A.M., Rahamtullah \& Waraich, E.A. 2010. Effect of rate and method of phosphorus use and irrigation scheduling on wheat yield and phosphorus use efficiency. Soil and Environ., 29(1): 15-22.

Rehman, O., Ranjha, A.M., Saleem, S. M. \& Khan, A.A. 2004. Phosphorus requirement of wheat using modified Freundlich model in Rasulpur soil series. Pakistan Journal of Agricultural Sciences, 41(1-2): 39-46.

Singh, T., Singh, K.N., Bali, Amarjit. S. \& Bhatt, G.N. 1995. Response of wheat (Triticum aestivum) genotypes to nitrogen and phosphorus. Indian J. Agron., 40(1): 99-101. 